\title{
Determinants Of Adolescents Sexual Behavior At Senior High School "X" In Banjarmasin
}

\author{
Nita Hestiyana ${ }^{1 *}$ \\ ${ }^{1}$ Academy of Midwifery Sari Mulia Banjarmasin Indonesia \\ *nita_hestiyana@akbidsarimulia.ac.id \\ Dini Rahmayani ${ }^{2}$ \\ ${ }^{2}$ High School of Health Sciences Sari Mulia Banjarmasin Indonesia \\ Dini_rahmayani@stikessarimulia.ac.id \\ Henny Auliana ${ }^{2}$ \\ ${ }^{2}$ High School of Health Sciences Sari Mulia Banjarmasin Indonesia \\ Henny_auliana@gmail.com
}

\begin{abstract}
Objective: To Analyze factors correlating with adolescents sexual behavior at Senior High School " $\mathrm{x}$ " Banjarmasin

Technology or Method: This study used an analytical survey with cross-sectional approach. The sample used is 65 people at Senior High School " $x$ " with simple random sampling technique. Dependent variables in this study were sex, knowledge about reproductive health, exposure with sources of information about sexuality, lifestyle, and romance. Independent variable was sexual behavior. Data were analyzed using Chi-Square test and if not qualified, then researcher use Fisher Exact test with a confidence level of $95 \%$.

Results: Result showed that there are correlation of knowledge about reproductive health $(\mathrm{p}=0,000$ $<\alpha=0,05)$, lifestyle $(\mathrm{p}=0,000<\alpha=0,05)$, romance $(\mathrm{p}=0,001<\alpha=0,05)$ with sexual behavior of adolescents at the school. There is no correlation of $\operatorname{sex}(p=0,243 \geq \alpha=0,05)$ and exposure with sexual sources information ( $p=0,100 \geq \alpha=0,05)$, with sexual behavior of adolescents in Senior High School "x" Banjarmasin

Conclusion: There are many factors that influence adolescent sexual behavior. Adolescents are expected to control themselves so as not to fall into negative sexual behavior
\end{abstract}

Keywords: Adolescent, Lifestyle, Romance, Sexual Behaviour 


\section{INTRODUCTION}

Until now the issue of sexuality has always been an interesting topic. This is possible because sexual problems have become a thing that is very attached to the human self. Sexuality cannot be avoided by people [1].

Unhealthy sexual behavior among teenagers, especially unmarried teenagers tends to increase. Sexual behavior in adolescents can be manifested in various behaviors, ranging from feelings of interest, dating, holding hands, to having sexual relations outside of marriage [2].

Research by Nursal (2007) with the title "Factors related to Sexual Behavior of Senior High School Students in Padang city" showed that there was a relationship between sex, age of puberty, knowledge, attitude, marital status of parents, parenting, long meetings with girlfriends and exposure to electronic media and mass media with sexual behavior [3]. Based on results of adolescent reproductive health surveys, Indonesian teenagers first dating at the age of 12 years. Teen dating behavior is also increasingly permissive as much as $92 \%$ of teenagers holding hands during courtship, $82 \%$ kissing, 63\% petting. These behaviors lead to teenage sexual intercourse [4].

The Result of Survey of Department Observer Community "LEMPEMA" from the year 2014-2016 turns out $65 \%$ adolescent of a girl in Banjarmasin ever have premarital sex. The results interviews of Department
Observer Community team with adolescents were obtained from premarital sex, information about early religious education, parental attention, premature dating due to promiscuity and economic factors [5].

According to Notoadmodjo (2012), factors affecting sexual behavior in adolescents include internal factors consisting of knowledge, health aspects, attitudes toward sexual and reproductive health services, behaviors, reproductive health, lifestyle, selfcontrol, social activity, self-confidence, age, religion, and marital status and external factors of contact with sources of information about sexuality, family, socio-cultural, values and norms as social supporters for certain behaviors [6].

The result of a preliminary study with short question and answer to the counseling teacher at the senior high school " $x$ " that every year the students who leave or change the school as many as 10-15 people every year with reason is changing schools, break school rules, do serious violations such as fighting and etc. Results of a brief question and answer with 10 teenage girls in high school "x", known to 8 people said ever hugged, kissed and two others say never been dating. This study aims to analyze factors related to sexual behavior in adolescents in Senior High School " $x$ ” Banjarmasin.

\section{RESEARCH METHODS}

This research uses analytic survey method with cross-sectional approach. The 
population of the case is all adolescent class $\mathrm{XI}$ in Senior High School "x" Banjarmasin as many as 187 people in 2017 . The sample on this research is determined by Solvin formula as many as 65 adolescents in Senior High School " $\mathrm{x}$ " using simple random sampling (Sabri, 2014 ) [7]. The dependent variable is sex, knowledge of reproductive health, exposure with sources of information about sexuality, lifestyle, and romance. Independent variable is sexual behavior. Data collection using questionnaire method by using ChiSquare test and if not qualified, then researcher use fisher exact test with a level of significance $95 \%(\alpha=0,05)$.

\section{RESULTS}

1. Univariate Analysis

a. Sex of Adolescents in Senior High School " $x$ " Banjarmasin

Table 1. Distribution frequency of Sex in Senior High School ' $\mathrm{x}$ ' Banjarmasin

\begin{tabular}{ccc}
\hline Sex & f & \% \\
\hline Male & 27 & 41,5 \\
Female & 38 & 58,5 \\
\hline Total & 65 & 100 \\
\hline
\end{tabular}

The result of the research showed that 38 adolescents of female $(58,5 \%)$ and male were 27 persons $(41,5 \%)$. b. Knowledge of Adolescents in Senior High School "x" Banjarmasin

Table 2. Distribution Frequency knowledge of Adolescents in Senior High School "x" Banjarmasin

\begin{tabular}{ccccccc}
\hline \multirow{2}{*}{ Knowledge } & \multicolumn{4}{c}{ Sex } & \multirow{2}{*}{ Total } \\
\cline { 2 - 6 } & \multicolumn{2}{c}{ Male } & \multicolumn{2}{c}{ Female } & & \\
\cline { 2 - 6 } & $\mathrm{F}$ & $\%$ & $\mathrm{~F}$ & $\%$ & $\mathrm{~N}$ & $\%$ \\
\hline Less & 13 & 20 & 23 & 35,4 & 36 & 55,4 \\
\hline Enough & 4 & 10,8 & 6 & 9,2 & 13 & 20 \\
\hline Good & 4 & 10,8 & 9 & 13,8 & 16 & 24,6 \\
\hline Total & 27 & 41,5 & 38 & 58,5 & 65 & 100 \\
\hline
\end{tabular}

The result of the research shows that the adolescents in Senior high School "x" Banjarmasin have the most knowledge about 36 persons $(55,4 \%)$ and at least have enough knowledge that is 13 persons $(20 \%)$

c. Sources of Information about Sexuality

Table 3. Distribution frequency Sources of Information about Sexuality in Senior High School 'x' Banjarmasin

\begin{tabular}{|c|c|c|c|c|c|c|}
\hline \multirow{3}{*}{$\begin{array}{c}\text { Sexual } \\
\text { Sources } \\
\text { Information }\end{array}$} & \multicolumn{4}{|c|}{ Sex } & \multirow{2}{*}{\multicolumn{2}{|c|}{ Total }} \\
\hline & \multicolumn{2}{|c|}{ Male } & \multicolumn{2}{|c|}{ Female } & & \\
\hline & $\mathrm{f}$ & $\%$ & $\mathrm{~F}$ & $\%$ & $\mathrm{n}$ & $\%$ \\
\hline $\begin{array}{c}\text { Not } \\
\text { Exposed }\end{array}$ & 20 & 30,8 & 31 & 47,7 & 14 & 21,5 \\
\hline Exposure & 7 & 10,8 & 7 & 10,8 & 51 & 78,5 \\
\hline Total & 27 & 41,5 & 38 & 58,5 & 65 & 100 \\
\hline
\end{tabular}

The results showed that adolescents in Senior High School "x" Banjarmasin exposed to Sexual sources information were 51 persons $(78,5 \%)$ and adolescents who were not exposed to sexual sources information were 14 persons $(21,5 \%)$.

d. Adolescents Lifestyle in Senior High School " $x$ " Banjarmasin

Table 4. Distribution Frequency of Adolescents of lifestyle in Senior High School " $x$ " Banjarmasin

\begin{tabular}{ccccccc}
\hline \multirow{2}{*}{ Lifestyle } & \multicolumn{4}{c}{ Sex } & \multicolumn{2}{c}{ Total } \\
\cline { 2 - 6 } & \multicolumn{2}{c}{ Male } & \multicolumn{2}{c}{ Male } & \\
\cline { 2 - 6 } & $\mathrm{F}$ & $\%$ & $\mathrm{~F}$ & $\%$ & $\mathrm{n}$ & $\%$ \\
\hline Negative & 13 & 20 & 22 & 33,8 & 35 & 53,8 \\
\hline Positive & 14 & 21,5 & 16 & 24,6 & 30 & 46,2 \\
\hline Total & 27 & 41,5 & 38 & 58,5 & 65 & 100 \\
\hline
\end{tabular}


The results showed that adolescents in Senior High School "x" Banjarmasin adolescents who have negative lifestyle were 35 persons $(53,8 \%)$ and adolescents who have a positive lifestyle were 30 persons $(46,2 \%)$.

e. Romance of Adolescents in Senior high School "x" Banjarmasin

Table 5. Distribution Frequency Romance of adolescents in Senior High School " $x$ " Banjarmasin

\begin{tabular}{ccccccc}
\hline \multirow{2}{*}{ Romance } & \multicolumn{4}{c}{ Sex } & \multirow{2}{*}{ Total } \\
\cline { 2 - 6 } & \multicolumn{2}{c}{ Male } & \multicolumn{2}{c}{ Female } & \multicolumn{2}{c}{$\%$} \\
\cline { 2 - 6 } & $\mathrm{F}$ & $\%$ & $\mathrm{~F}$ & $\%$ & $\mathrm{n}$ & $\%$ \\
\hline $\begin{array}{c}\text { Ever/is in a } \\
\text { relationsip }\end{array}$ & 4 & 6,2 & 3 & 4,6 & 58 & 89,2 \\
\hline Never & 23 & 35,4 & 35 & 53,8 & 7 & 10,8 \\
\hline Total & 27 & 41,5 & 38 & 58,5 & 65 & 100 \\
\hline
\end{tabular}

The results showed that adolescents in Senior High School "x" Banjarmasin with the classification ever/is in a relationship were 58 persons $(89,2 \%)$ and adolescents who never dating were seven of persons $(10,8 \%)$.

f. Sexual Behavior of Adolescents in Senior High School " $x$ " Banjarmasin

Table 6. Distribution Frequency Sexual Behaviour of adolescents in Senior High School "x" Banjarmasin

\begin{tabular}{ccccccc}
\hline \multirow{2}{*}{$\begin{array}{c}\text { Sexual } \\
\text { Behaviour }\end{array}$} & \multicolumn{4}{c}{ Sex } & \multicolumn{2}{c}{ Total } \\
\cline { 2 - 6 } & \multicolumn{2}{c}{ Male } & \multicolumn{2}{c}{ Female } & \multicolumn{2}{c}{} \\
\cline { 2 - 6 } & $\mathrm{F}$ & $\%$ & $\mathrm{~F}$ & $\%$ & $\mathrm{n}$ & $\%$ \\
\hline Negative & 13 & 20 & 25 & 38,5 & 38 & 58,5 \\
\hline Positive & 14 & 21,5 & 13 & 20 & 27 & 41,5 \\
\hline Total & 27 & 41,5 & 38 & 58,5 & 65 & 100 \\
\hline
\end{tabular}

The results showed that adolescents in Senior High School "x" Banjarmasin with the classification of negative sexual behavior were 38 persons $(58,5 \%)$ and adolescents with positive sexual behavior were 27 persons $(41,5 \%)$.
2. Bivariate Analysis

a. Relationship Sex with Sexual Behaviour of Adolescents in Senior High School " $\mathrm{x}$ ” Banjarmasin

Table 7. Relationship Sex with Sexual Behaviour of Adolescents in Senior High School " $x$ " Banjarmasin

\begin{tabular}{ccccccc}
\hline Sex & \multicolumn{3}{c}{ Sexual Behavior } & \multirow{2}{*}{ Total } \\
\cline { 2 - 5 } & \multicolumn{2}{c}{ Negative } & \multicolumn{2}{c}{ Positive } & & \\
\cline { 2 - 6 } & $\mathrm{F}$ & $\%$ & $\mathrm{~F}$ & $\%$ & $\mathrm{f}$ & $\%$ \\
\hline Male & 13 & 48,1 & 14 & 51,9 & 27 & 100 \\
\hline Female & 25 & 65,8 & 13 & 34,2 & 38 & 100 \\
\hline Total & 38 & 58,5 & 27 & 41,5 & 65 & 100 \\
\hline \multicolumn{7}{c}{$\mathbf{p = 0 , 2 4 3}(\geq \boldsymbol{\alpha}=\mathbf{0 , 0 5})$} \\
\hline
\end{tabular}

The result of research from 65 Adolescents in Senior High School "x" Banjarmasin showed that adolescent of female sex with negative sexual behavior were 25 persons $(65,8 \%)$. The result of analysis with chi-square test showed that $p=0,243(\geq \alpha=0,05)$ or it can be said that there is no significant relationship between sex with sexual behavior of adolescent in Senior High School "x" Banjarmasin

b. Relationship Knowledge with Sexual Behaviour of Adolescents in Senior High School " $x$ ” Banjarmasin

Table 8.Relationship Knowledge with Sexual Behaviour of Adolescents in Senior High School "x" Banjarmasin

\begin{tabular}{ccccccc}
\hline \multirow{2}{*}{ Knowledge } & \multicolumn{3}{c}{ Sexual Behaviour } & \multirow{2}{*}{ Total } \\
\cline { 2 - 6 } & \multicolumn{2}{c}{ Negative } & \multicolumn{2}{c}{ Positive } & & \\
\cline { 2 - 6 } & $\mathrm{F}$ & $\%$ & $\mathrm{~F}$ & $\%$ & $\mathrm{f}$ & $\%$ \\
\hline Less & 32 & 86,9 & 4 & 11,1 & 36 & 100 \\
Enough & 6 & 46,2 & 7 & 53,8 & 13 & 100 \\
Good & 0 & 0 & 16 & 100 & 16 & 100 \\
\hline Total & 38 & 58,5 & 27 & 41,5 & 65 & 100 \\
\hline \multicolumn{7}{c}{$\mathrm{p}=0,000(<\alpha=0,05)$} \\
\end{tabular}

The result of the research from 65 Adolescents in Senior High School "x" Banjarmasin showed that adolescents with 
less knowledge have negative sexual behavior were 32 persons $(86,9 \%)$. The result of analysis with chi-square test showed that $\mathrm{p}=0,000(<\alpha=0,05)$ or it can be said that there is a significant relationship between knowledge of adolescents sexual behavior in Senior High School "x" Banjarmasin.

c. Relationship Source of Information about Sexuality with Sexual Behaviour of Adolescents in Senior High School " $x$ " Banjarmasin

Table 9. Relationship Source of Information about Sexuality with Adolescents Sexual Behaviour in Senior High School "x" Banjarmasin

\begin{tabular}{ccccccc}
\hline \multirow{2}{*}{$\begin{array}{c}\text { Sexual Source } \\
\text { information }\end{array}$} & \multicolumn{3}{c}{ Sexual behavior } & \multirow{2}{*}{ Total } \\
\cline { 2 - 5 } & Negative & \multicolumn{2}{c}{ Positive } & & \\
\cline { 2 - 6 } & $\mathrm{f}$ & $\%$ & $\mathrm{~F}$ & $\%$ & $\mathrm{f}$ & $\%$ \\
\hline Not Exposed & 5 & 35,7 & 9 & 64,3 & 14 & 100 \\
Exposure & 33 & 64,7 & 18 & 35,3 & 51 & 100 \\
\hline Total & 38 & 58,5 & 27 & 41,5 & 65 & 100 \\
\hline & $\mathrm{p}=0,100(\geq \alpha=0,05)$ & &
\end{tabular}

Result of research from 65 adolescent in Senior High School "x" Banjarmasin showed that adolescents exposed information source with negative sexual behavior were 33 persons $(64,7 \%)$. The result of analysis with Fisher exact test showed that $\mathrm{p}=0,100(\geq \alpha=0,05)$ or can be said that there is no significant relationship between exposure to sexual source information with the sexual behavior of adolescent in Senior High School "x" Banjarmasin. d. Relationship Lifestyle with Sexual Behaviour of Adolescents in Senior High School "x" Banjarmasin

Table 10. Relationship Lifestyle with Sexual Behaviour of Adolescents in Senior High School " $x$ " Banjarmasin

\begin{tabular}{ccccccc}
\hline \multirow{2}{*}{ Lifestyle } & \multicolumn{3}{c}{ Sexual Behaviour } & \multicolumn{2}{c}{ Total } \\
\cline { 2 - 5 } & \multicolumn{2}{c}{ Negative } & \multicolumn{2}{c}{ Positive } & \multicolumn{2}{c}{} \\
\cline { 2 - 6 } & $\mathrm{F}$ & $\%$ & $\mathrm{~F}$ & $\%$ & $\mathrm{f}$ & $\%$ \\
\hline Negative & 34 & 97,1 & 1 & 2,9 & 35 & 100 \\
Positive & 4 & 13,3 & 26 & 86,7 & 30 & 100 \\
\hline Total & 38 & 58,5 & 27 & 41,5 & 65 & 100 \\
\hline \multicolumn{4}{c}{$\mathrm{p}=0,000(\geq \alpha=0,05)$} \\
\end{tabular}

The result of the research from 65 adolescents in Senior High School "x" Banjarmasin showed that adolescents had a negative lifestyle with negative sexual behavior were 34 persons $(97,1 \%)$. The result of analysis with chi-square test showed that $\mathrm{p}=0,000(<\alpha=0,05)$ or it can be said that there is a significant relationship between lifestyle with the sexual behavior of adolescent in Senior High School "x" Banjarmasin.

e. Relationship Romance with Sexual Behaviour of Adolescents in Senior High School "x" Banjarmasin

Table 11. Relationship Romance with Sexual Behaviour of Adolescents in Senior High School " $x$ " Banjarmasin

\begin{tabular}{ccccccc}
\hline \multirow{2}{*}{ Romance } & \multicolumn{3}{c}{ Sexual Behaviour } & \multirow{2}{*}{ Total } \\
\cline { 2 - 5 } & \multicolumn{2}{c}{ Negative } & \multicolumn{2}{c}{ Positive } & & \\
\cline { 2 - 5 } & $\mathrm{F}$ & $\%$ & $\mathrm{~F}$ & $\%$ & $\mathrm{~F}$ & $\%$ \\
\hline $\begin{array}{c}\text { Ever/is in a } \\
\text { relationsip } \\
\text { Never }\end{array}$ & 38 & 65,5 & 20 & 34,5 & 58 & 100 \\
\hline Total & 0 & 0 & 7 & 100 & 7 & 100 \\
\hline & 38 & 58,5 & 27 & 41,5 & 65 & 100 \\
\hline & $\mathrm{p}=0,001(<\alpha=0,05)$ & & &
\end{tabular}

The result of the research from 65 adolescents in Senior High School "x" Banjarmasin showed that adolescents who are in a relationship had negative 
sexual behavior were 38 persons (65.5\%). The result of analysis with Fisher exact test showed that $p=0,001(\geq \alpha=0,05)$ or can be said that there is significant relation between romance with the sexual behavior of adolescent in Senior High School "x" Banjarmasin.

\section{IV.DISCUSSION}

1. Relationship Sex with Sexual Behaviour of Adolescents in Senior High School "x" Banjarmasin

Chi-square test results showed that there is no significant relationship between sex with the sexual behavior of adolescents in Senior High School "x" Banjarmasin. Adolescents who have positive or negative sexual behavior don't look at the sex, this is due to many other factors that can affect sexual behavior such as the environment of residence and lifestyle of adolescents.

The results of this study same with the study of Mira Ahmad (2012), which showed that there is no significant relationship between sex with the sexual behavior of adolescent girls [8].

Based on table 7, the most adolescents were the result of female sex with negative sexual behavior. Research of Tyden, et al (2012) with the title "A Repeated Survey of Sexual Behavior Among Female University Students in Sweden" concluded that the sexual lifestyle of female university students has become riskier and this might have serious consequences for their sexual and reproductive health in the future [9]. Young women are more likely to have negative sexual behavior because the curiosity of girls is higher than that of men. Young women are expected to keep themselves and avoid from negative sexual behavior.

2. Relationship Knowledge with Sexual Behaviour of Adolescents in Senior High School " $x$ " Banjarmasin

Based on the results of statistical tests, the results showed that there is a significant relationship between knowledge of the sexual behavior of adolescent in Senior High School "x" Banjarmasin.

Table 8 showed that most adolescents are less knowledgeable with negative sexual behavior. Behavior-based on knowledge is better than behavior that is not based on knowledge. Less knowledge about sexual problems makes teens want to find out more than different types of information sources. Sometimes the information obtained is misleading and incomplete. Inadequate or half knowledge not only encourages teenagers to try, but also leads to misperceptions (Notoadmodjo, 2012) [6].

In a study by Choi et al (2016) with the title “A Study of Sexual Behavior, Sexual Knowledge, and Sexual Assertiveness 
among Korean College Students" showed that higher scores on sexual behavior are related to lower sexual knowledge. Therefore, sexual education is provided from an early age with a timely sexual education program that needs to be developed in the public education curriculum. The sexual education program and counseling concerned with the needs of college students are necessary for youth and society [10].

3. Relationship Source of Information about Sexuality with Sexual Behaviour of Adolescents in Senior High School " $x$ " Banjarmasin

The result of analysis with Fisher exact test showed that there is no significant relationship between exposure to sexual source information with the sexual behavior of adolescent in Senior High School "x" Banjarmasin. Sources of sexual information can be from the mass media (mass or electronic), parents, health workers, teachers, and friends. The impact of pornographic media on the sexual behavior of adolescents is a very big influence. Reading and watching pornographic films will motivate and stimulate adolescents to imitate or practice them (Samino, 2012) [11].

In a study by Collin et al (2004) with the title "Watching Sex on Television Predicts Adolescent Initiation of Sexual Behavior" concluded that Watching sex on
TV predicts and may hasten adolescent sexual initiation. However, reducing adolescent exposure to sexual information sources may delay adolescent sexual initiation. Alternatively, parents may be able to reduce the effects of sexual content by watching TV with their teenaged children and discussing their own beliefs about sex [12]. After that, although adolescents are exposed to exposure to a sexual source of information, if the adolescent is able to control themselves and get good information then it will not affect adolescent sexual behavior.

4. Relationship Lifestyle with Sexual Behaviour of Adolescents at Senior High School " $x$ " Banjarmasin

The result of analysis with chisquare test showed that there is a significant relationship between lifestyle with the sexual behavior of adolescent in Senior High School "x" Banjarmasin.

Based on table 10, most of the adolescents with negative lifestyle have negative sexual behavior.

In a study by Uitenbroek DG. (1994) with the title "The Relationship between Sexual Behavior and Health Lifestyle" concluded that there was a strong relationship between indicators of a healthy lifestyle and sexual behavior seem to be a factor to be considered in the development of future AIDS/HIV-related health [13]. 
In a journal with the title "Sex and Aging in the City: Singapore" showed that sex life is determined not only by physiological, but also cultural, social and lifestyle factors. (Goh, et al., 2004) [14].

According to Hurlock, sexual behavior is strongly influenced by the social environment, especially during puberty where peer influence is greater than the elderly. Lifestyle has a major influence on adolescent sexual behavior, so that when adolescents have a social environment or have friends who like to engage in sexual behavior at risk, then the adolescent will be affected and participate to do.

5. Relationship Romance with Sexual Behaviour of Adolescents in Senior High School "x" Banjarmasin

The result of analysis with Fisher exact test showed that there is significant relation between romance with the sexual behavior of adolescent in Senior High School "x" Banjarmasin.

Table 11 showed that adolescents who are in a relationship had negative sexual behavior. Sexual intercourse in adolescents is generally due to dating or romance and some of them are oriented towards gratification. Courtship is not a strange thing for adolescents is even a demands of the times and if not have a girlfriend was not modern. If you have a girlfriend already have "standard" what to do. Therefore, adolescents who do not have a strong self-concept can be affected by negative sexual behavior. Things that need to be known by adolescents were dating is not a sexual experiment but is a process of knowing and understanding the opposite sex is expected to become a life partner. The meeting time is too little or too long it is possible to happen something that is not desired. If the time is too short, then the time will be used as effectively as possible to release each other longs, while if too long will give an opportunity to try new things so as not to bore.

\section{CONCLUSION}

There are many factors that influence adolescent sexual behavior. In this study, factors related to sexual behavior of adolescents were a lifestyle, romance, and knowledge of adolescents about reproductive health. The adolescent is expected to control them so as not to fall into negative sexual behavior.

\section{REFERENCES}

[1] Hurlock, B. Elizabeth. Psychology of Development V-Edition. Jakarta: Erlangga. 2011.

[2]. Sarwono, W.S, Youth Psychology Jakarta: Raja Grafindo Persada, 2012.

[3]. Nursal DGA. Factors related to the sexual behavior of high school students in the city of Padang in 2007 (thesis). Padang: 
Faculty of Public Health Andalas University Vol 2 No. 2, 2008.

[4]. KPAI. First Dating of Indonesian Children Age 12 Years. [on line]. http: // KPAI First Dating of Indonesian Children Age 12 Years Lifestyle Tempo.co.htm. 2012.

[5]. Media OnLine Sound of Borneo http://www.suarakalimantan.com/2016/1 2/Survey-Results-of Adolescent-GirlsBanjarmasin-65-Not Virgin/ 2016.

[6] Notoatmojdo, Soekidjo. Education And Health Behavior. Jakarta: Rineka Cipta. 2012.

[7]. Sabri, Luknis. Health Statistics. Jakarta: Rajawali Pers. 2014.

[8]. Mira Ahmad. Factors Affecting with Free Sex on Adolescent girls at Senior High School 29 Semarang. Health Journal: [Internet] can be accessed at http //: www.healthy.co.id. 2012.

[9]. Tyden T, Palmquist M, Larsson M. A Repeated Survey of Sexual Behaviour Among Female University Students in Sweden. PUBMED. 91(2): pp. 215-9. doi: $\quad$ 10.1111/j.1600-0412.2011.0129, 2012.

[10] Chol, Jung-Hyun, Miok Kim. A Study on Sexual Behavior, Sexual Knowledge, and Sexual Assertiveness among Korean College Students. Indian Journal of Science and Technology. Vol 9(29), DOI: 10.17485/ijst/2016/v9i29/94766, 2016.

[11] Samino. Analysis of Adolescents Sexual Behaviour at SMAN 14 Bandar Lampung. World Journal of Public Health. 2012.

[12]. Collins, et all. Watching Sex on Television Predicts Adolescent Initiation of Sexual Behavior. American Academy of Pediatrics Journals. 2004: Vol 114/ISSUE 3

[13] Uitenbroek DG. The Relationship between Sexual Behaviour and Health Lifestyle. PUBMED. 1994: 6(2):237-46

[14] Goh VH, Tain CF, Tong YY, Mok PF, $\mathrm{Ng}$ SC. Sex and Aging in the city; Singapore. PUBMED. 2004: Sep;7(3):219-26.F 